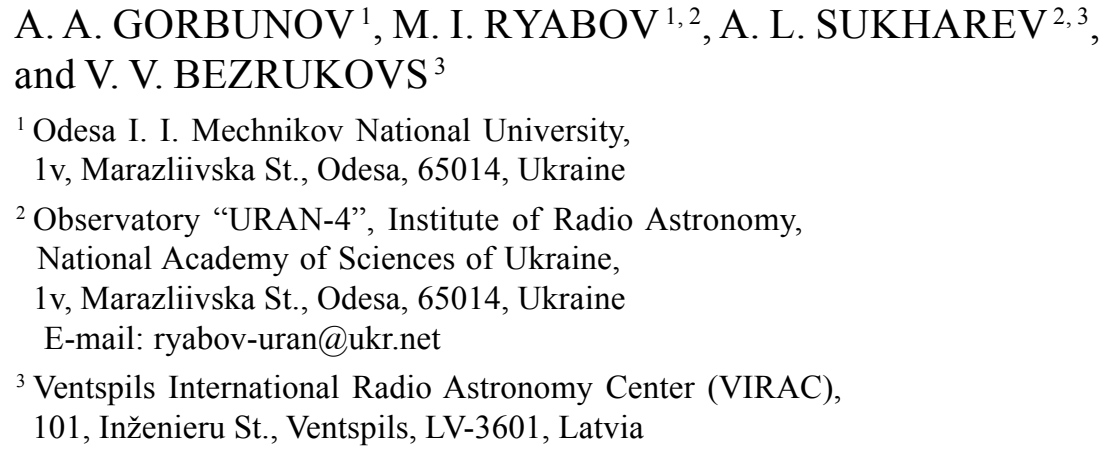

\title{
PERIODIC AND SPORADIC VARIATIONS IN THE SPECTRAL FLUX DENSITY OF THE CAS A SUPERNOVA REMNANT
}

Purpose: Based on the long-term study data in all radio spectrum ranges, the nature of deviations of spectral flux density of the Cas A supernova remnant from the tendency of its secular decrease is considered. The aim of this work is determining the presence of quasiperiodic variations and sporadic changes in the Cas A spectral radiation flux density depending on frequency. Design/methodology/approach: The main database is using the published results obtained with the method of absolute measurements of the Cas A spectral radiation flux density in a wide range from millimeter to decimeter wavelengths, as well as the results obtained with the method of relative measurements, i.e. the ratio of the flux densities of the Cas A supernova remnant and radio galaxy Cyg A, this latter being used as a reference source in the meter wavelength range. For making comparison with the aforesaid data obtained with different methods, the results of a long-term monitoring (since 1987) of the variation of the ratio of the spectral flux densities of Cas A and Cyg A made with the URAN-4 radio telescope of the Institute of Radio Astronomy of the National Academy of Sciences of Ukraine at $25 \mathrm{MHz}$ were used.

Findings: As a result of the analysis of the observed data for the Cas A radiation flux density in the entire radio wavelength range, the existence of quasiperiodic variations in the range from millimeter to meter wavelengths within 2 to 9 years has been noted. The reason for the detected quasiperiodic variations can be the processes in the Cas A remnant itself. In the decameter wavelength range, according to monitoring data obtained with the URAN-4 radio telescope, the seasonal-diurnal and long-term variations are noted, being associated with changes in the ionosphere state in the solar activity cycle, with some weak appearance of the secular decrease of the Cas A radiation flux. The presence of sporadic variations in the ratio of the spectral flux densities of Cas A and Cyg $A$ is associated with the effect of the increased solar activity. For explaining the lowering of the Cas A spectral flux density to the Cyg A level and maintaining the excess of the Cas A flux at decameter waves, the quasi-simultaneous observations made with radiotelescopes for different wavelength ranges will be required.

Conclusions: The evolution of the Cas A supernova remnant remains the focus of interest of current research efforts. An intriguing moment was the discovery of a point X-ray source in the center of radio source Cas A as a possible supernova remnant. The role of this source in the Cas A radio flux secular decrease and in its variations needs to be clarified. A detailed analysis of the long-term data and making quasi-simultaneous observations will allow to reveal the processes occurring in the radio source itself and to determine the influence of the ionosphere state on the results of measurements. A joint program is suggested for observations of Cas A and Cyg A flux variations with the RT-32 and RT-16 radio telescopes, the LOFAR element of the Ventspils International Radio Astronomy Center (Latvia), and the URAN, UTR-2 and GURT radio telescopes of the Institute of Radio Astronomy of the National Academy of Sciences of Ukraine.

Key words: Cas A, secular radiation flux decrease, supernova remnant, ionosphere, solar activity

\section{Introduction}

The Cas A radio source (3C 461) was discovered in 1947 and identified with a supernova remnant (SNR) in 1950. The object immediately attracted attention, as it turned out to be the most powerful source in the radio-frequency region up to $1 \mathrm{GHz}$, with the maximum flux at $16.5 \mathrm{MHz}$. The major interest in its studying lies in the fact that it is the most powerful source in the sky, and it can be used as a calibration source. The second important factor is the presence of a secular decrease in the Cas A flux, as a young remnant of a supernova explosion. Thus, when Cas A is used as a primary calibration source, it is necessary to take into account the secular flux decrease, which, depending on frequency, can have an irregular character. Of particular interest are deviations from the secular flux decrease, the cause of which can be the processes in the radio source itself and the influence of the environment (interstellar, interplanetary medium and ionosphere). 
Due to the fact, that carrying out absolute measurements the spectral flux of radio sources requires special technical support, such observations have not become a constant practice. From the very beginning of the research, the relative method of changes in the spectral flux density was used, based on the comparison of a relatively more stable and comparable in terms of spectral density the Cyg A radio galaxy flux. It is assumed that Cyg A has a constant radio flux. Episodic observations in this mode were made at the variety of radio telescopes and wavelengths, for example, at the Jodrell Bank Observatory (Mark 2 and Lovell Telescope), Clark Lake Radio Observatory, Mullard Radio Astronomy Observatory (Ryle Telescope), Pushchino Radio Astronomy Observatory (DKR-1000 Telescope), NIRFI radio telescopes, UTR-2, URAN, GURT, VLA, LOFAR, ALMA, and many others. The disadvantage of most of these observations is their episodic nature and heterogeneity of data.

On the basis of observational data, a theory of secular flux decrease has been developed, which describes a monotonic decrease in the spectral flux density.

In [1], the use of Cas A as a secondary calibrator is considered, taking into account the corrections for the secular flux decrease. It is assumed that this achieves the accuracy of $5 \%$. All observational data from the millimeter to decameter wavelength range show the difference from the monotonic trend. In particular, among them one can distinguish some periodic ones, which can be associated with the evolution of the source itself and episodic ones due to the influence of the environment. This work is a presentation of the effects of deviation of the spectral flux density from millimeter to decameter wavelengths.

\section{Research Results Using the Absolute Measurement Method}

Long-term observation cycles of the Cas A spectral flux density evolution at millimeter waves, using the technique of absolute measurements, were made at the wavelength of $8.1 \mathrm{~mm}$ at the Kara-Dag NIRFI radio astronomy station with the $7-\mathrm{m}$ diameter radio telescope [2].

The rate of secular flux decrease was $0.56 \%$ per year, according to the formula

$$
\frac{1}{S_{v}} \frac{\mathrm{d} S_{v}}{\mathrm{~d} t}=-(0.56 \pm 0.01)
$$

The authors of this work note that the drop in the flux is not constant, and alternately accelerates and decelerates over 10-15 years [3]. Moreover, periodic changes in the spectral index value determined by the formula

$$
\lg S=B-\alpha \lg v \text {. }
$$

Here $S$ is the spectral flux density (Jy) at frequency $v(\mathrm{MHz}), \alpha$ is the spectral index, parameter $B$ provides absolute calibration. It turned out that values $B$ and $\alpha$ depend on time. According to the measurements at 500 and $9770 \mathrm{MHz}$, the secular flux decrease for the period since 1953 till 1984 amounted to $0.66 \%$ and $0.43 \%$ per year, respectively. Temporary changes of $B$ and $\alpha$ for the 0.5 to 10 $\mathrm{GHz}$ frequency range are shown in Figs. 1 and 2.

The results of absolute observations at $1405 \mathrm{MHz}$, show that the rate of decrease of the Cas A flux density by 1970 was $d=(0.886 \pm 0.021)$ per cent $\cdot \mathrm{yr}^{-1} \quad$ [5] (an example is shown in Fig. 3). Subsequently, since 1970 till the end of the 1990s, it slowed down to $d=\left(0.516_{-0.054}^{+0.056}\right)$ per cent $\cdot \mathrm{yr}^{-1}$, then accelerated again and by the end of 2010 , turned out to be equal to $d=\left(0.798_{-0.050}^{+0.058}\right)$ per cent $\cdot \mathrm{yr}^{-1}$. Thus, in this range, long-term variations in flux density changes appear.

As of 2010, the rate of secular decrease of spectral flux density decreased to $d=(0.654 \pm$ $0.019)$ per cent $\cdot \mathrm{yr}^{-1}$. The periodicity of this pheno-
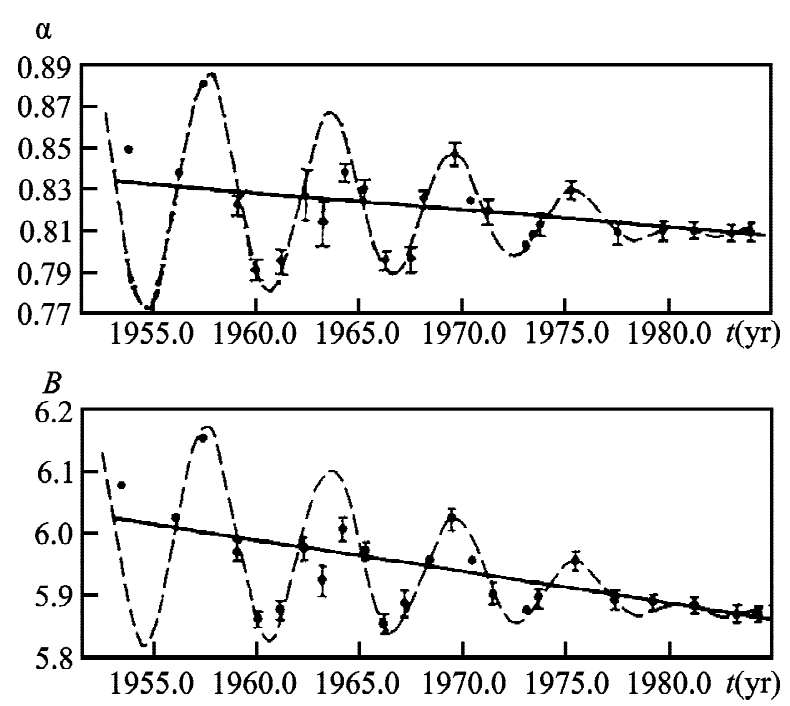

Fig. 1. Time dependence of the spectral index $\alpha$ (top panel) and parameter $B$ (bottom panel) for the Cas A radio source. Variations, relative to the linear trend of the secular flux decrease, are seen well approximated by the decaying sinusoid (V. P. Ivanov and K. S. Stankevich, 1989) [4] 


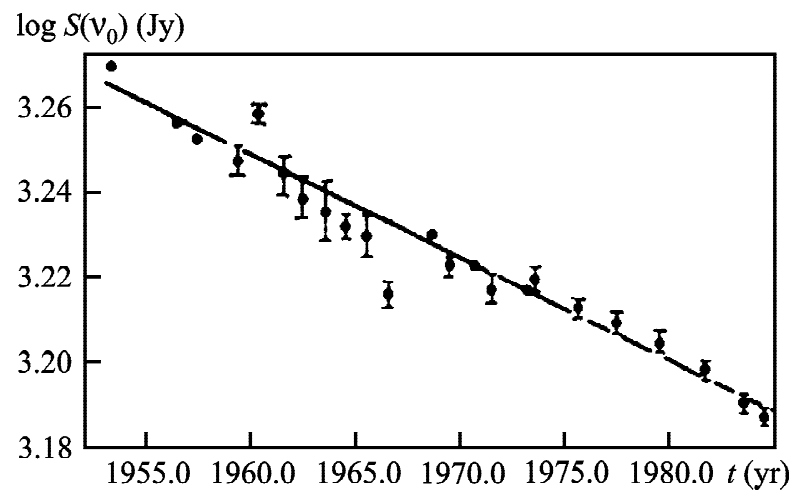

Fig. 2. Time dependence of the Cas A radio source flux density observed at 2013.6 MHz (V. P. Ivanov and K. S. Stankevich, 1989) [4]

menon has not been determined clearly, due to the limited duration of the observation time interval. At the same time, on the plot, in the time interval since 1995 till 2015, an irregular deviation of the flux from the trend of secular change, being of non-periodic nature, can be seen.

\section{Research Results Based on the Cas A Flux Relative Measurements}

A similar type of deviation from the secular decrease trend in the spectral flux density is observed at the meter wavelengths, when carrying out programs of relative measurements. In $[6,7]$, an episodic devia- tion from the trend of the secular decrease in the ratios of the flux densities of Cas A and Cyg A at $290 \mathrm{MHz}$ is noted. An example is shown in Fig. 4.

In [8], the data on changes in the Cas A to Cyg A flux ratio at the wavelength of $4.2 \mathrm{~m}$ were given. For a 50-year observation period, the flux ratio has dropped by a factor of one and a half, with an average annual rate about $0.7 \%$ per year. This decrease was not strictly monotonic, but variable in nature with an approximate period from 2.5 to 3 years.

The authors of work [9] used archival data of observations of the Cas A and Cyg A flux density ratio variation obtained with the VLA, covering the last 15 years at $74 \mathrm{MHz}$, in combination with the new data from the Long Wavelength Demonstrator Array (LWDA) and the data from literature covering the last 50 years, in order to investigate the evolution of Cas $\mathrm{A}$ at low radio frequencies. The data have been obtained on a stable decrease in the Cas A and Cyg A flux ratio over the entire period of 50 years with the annual decrease of $0.7-0.8 \%$ per year.

At the same time, subtraction of the secular decrease trend in the Cas A and Cyg A flux density ratios reveals quasiperiodic variations (an example is shown in Fig. 5). The top panel of Fig. 5 shows the main periods of variations in the Cas A and Cyg A flux density ratio.

The bottom panel shows the data of the model of periodic changes in the Cas A to Cyg A flux ratio after
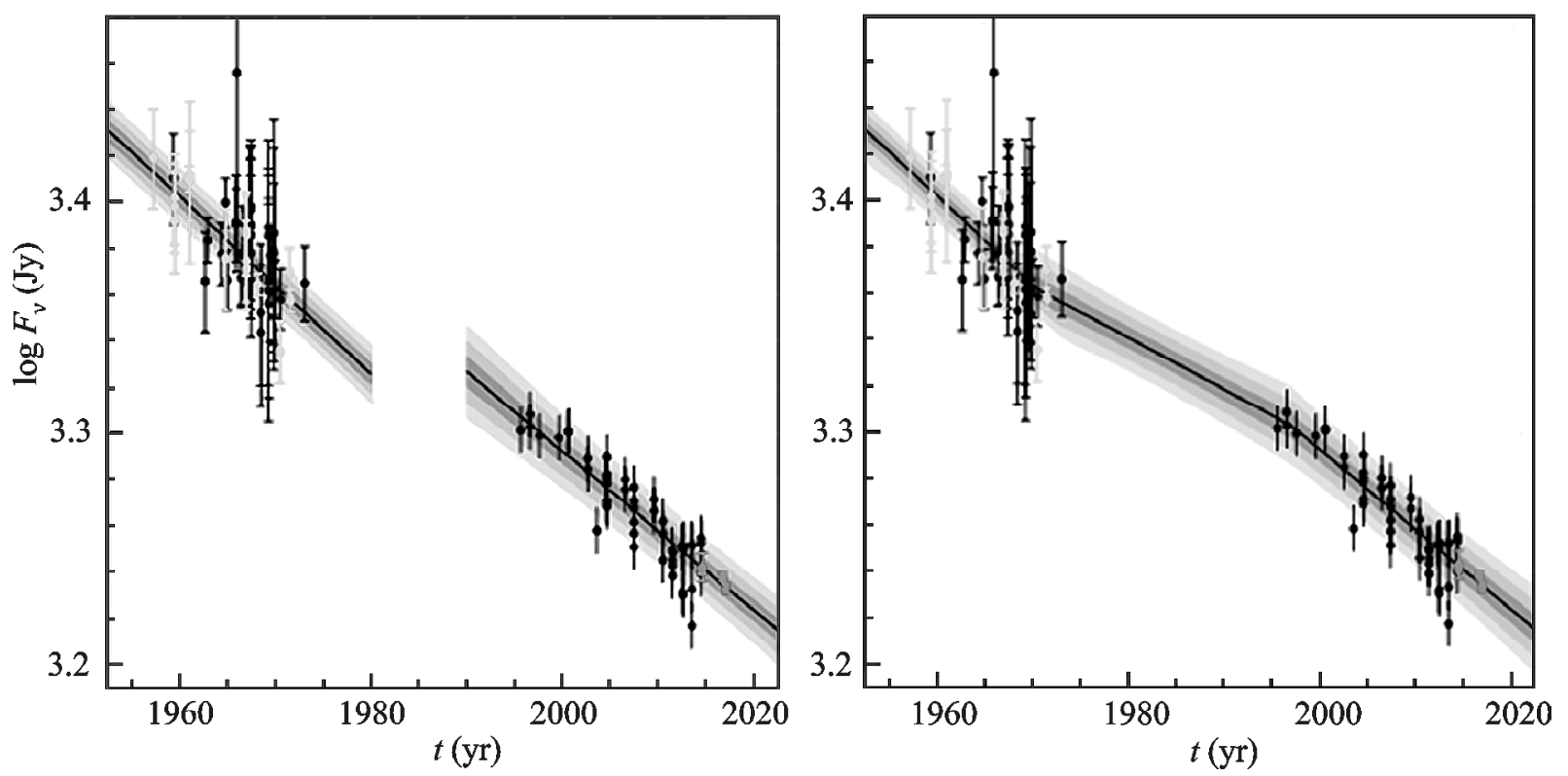

Fig. 3. Representation of data on the Cas A flux decrease at $1405 \mathrm{MHz}$, the frequency, which shows the change in the rate of secular decrease in the spectral flux density (A. S. Trotter at al., 2017) [5]. 
$S_{290 \mathrm{MGz}}^{\mathrm{CasA}}(t) / S_{290 \mathrm{MGz}}^{\mathrm{CygA}}$

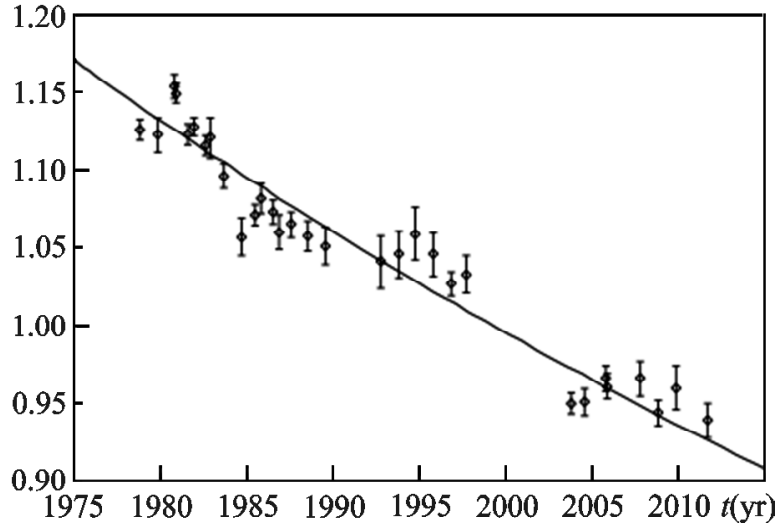

Fig. 4. The Cas A and Syg A flux density ratios at $290 \mathrm{MHz}$, the secular flux decrease is marked by a trend (E. N. Vinyaikin, 2014) [7] the secular flux decrease model subtraction of $0.84 \%$ per year. The obtained result was described by a fourcosine model, where the gray area is the model error due to the fitting parameter and the correlation matrix. The possible period for the flux density fluctuations is 5-10 years, presumably with four shorter periods. This became possible due to the extensive data set collected as a result of several decades of observations and allowed to refine the secular flux decrease, obtained in paper [1], and being about $0.8 \%$ per year remains for 50 years at this value.

A significant number of works on the observation of secular changes in the Cas A and Cyg A flux density ratios were carried out at the frequency of $38 \mathrm{MHz}$. Fig. 6 shows the presence of a secular decrease trend and possible quasiperiodic variations of that ratio from 2 to 9 years [10].
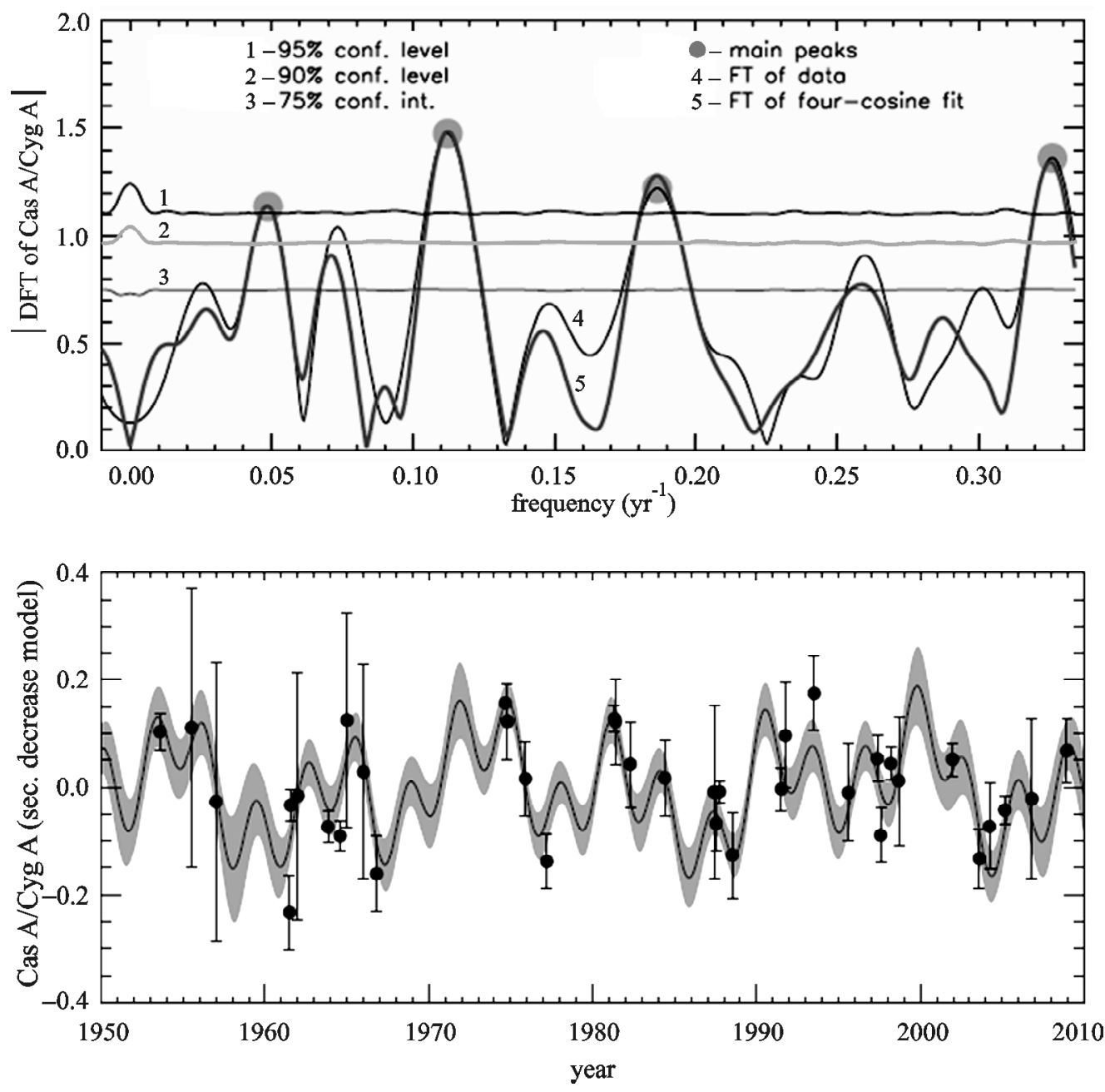

Fig. 5. Quasiperiodic variations of the Cas A and Cyg A flux density ratio at $80 \mathrm{MHz}$. The top plot is the Fourier periodogram for irregular time series, the bottom panel shows a trigonometric polynomial plotted by using the quasi-periods from the top graph, inscribed at the original data points (after subtracting the secular flux decline trend) (J. F. Helmbolt and N. E. Kassim, 2009) [9] 

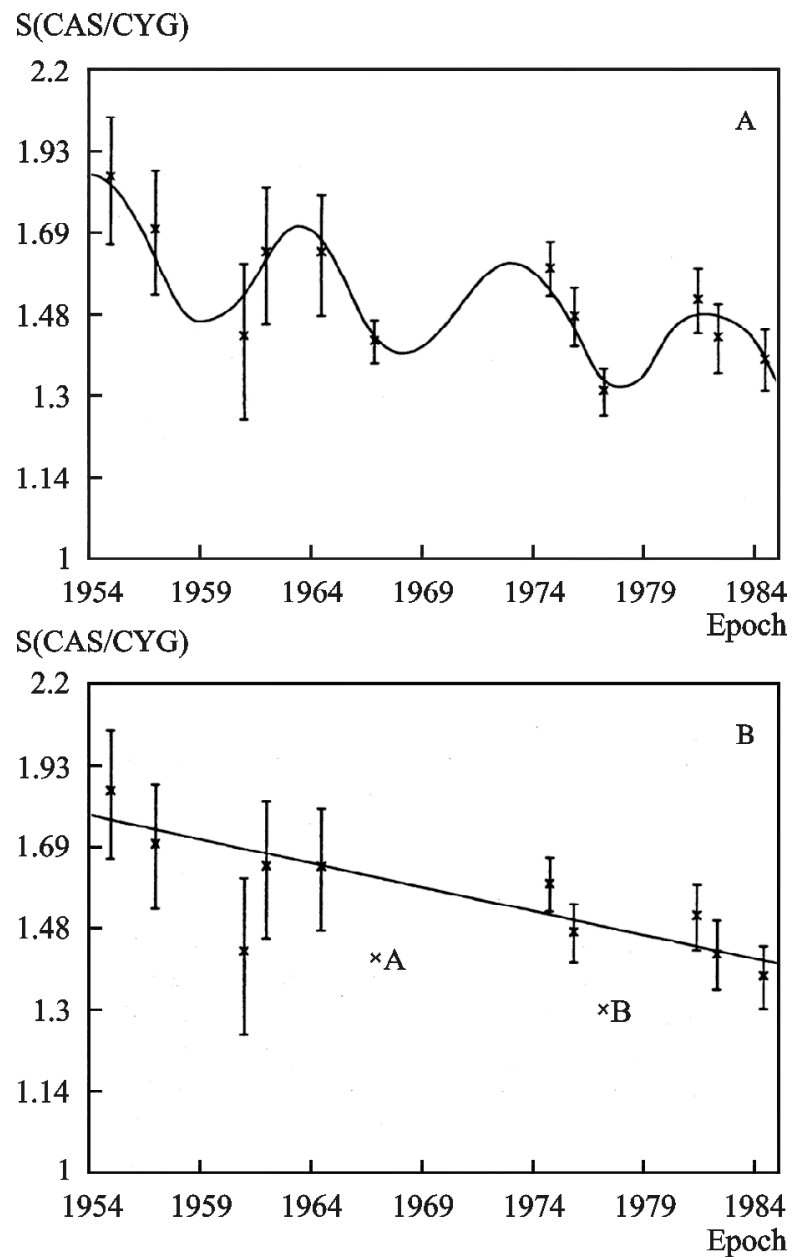

Fig. 6. Variations of the Cas A and Cyg A flux density ratio at $38 \mathrm{MHz}$ (L. T. Walczowski and K. L. Smith, 1985) [10]. Two options for understanding the observation results are shown, either a quasi-sinusoidal wave (top panel) or a linear downtrend (bottom panel) with resembling a drop-out points

Sharp changes in the Cas A and Cyg A flux density ratios can be explained by different influence of the ionosphere on the Cas A and Cyg A fluxes. Also, some individual episodes of variations in the Cas A to Cyg A flux ratios can be associated with the evolution of the Cas A source itself.

\section{Results of Monitoring the Decameter Range Observations with the URAN-4 Radio Telescope}

At the URAN-4 radio telescope of the Institute of Radio Astronomy of the National Academy of Sciences of Ukraine, since its putting into operation in 1987 and untill now (more than 30 years of observations), monitoring of the fluxes of powerful space radio sour- ces - 3C 144 (supernova remnant Taurus A), 3C 274 (radio galaxy Virgo A), 3C 405 (radio galaxy Cyg A), 3C 461 (supernova remnant Cas A) - have been carried out [11-13]. Some of the main results obtained are described below. In the time interval of using the analog recordings, since 1987 till 1992, the observations were made in separate monthly sessions of $10-12$ days at 20 and $25 \mathrm{MHz}$. With the use of digital recording (after 1998), the observations were made continuously, with the exception of the time of VLBI observation sessions and maintenance service periods. As a result of data processing, the average values of the Cas A and Cyg A flux density ratios were obtained for a session or a month of observations. Such an extensive observational material makes it possible to trace in detail the presence of various factors influencing the observations of radio sources in the decameter wavelength range, including seasonal-diurnal effects and appearance of solar and geomagnetic activity. Based on the results of observations at the URAN-4 radio telescope, it has been shown that the amplitude of the seasonal-daily effects of the Cas A to Cyg A flux ratio depends on the time of day and the season of their culmination and varies within 1.3 to 1.7 .

Further, according to the results of long-term observations obtained with the URAN-4 radio telescope, it was found that for the correct consideration, the change in the ratio of spectral flux densities of Cas A and Cyg A has to be best divided into two data sets (see examples in Figs. 7 and 8) in connection with a long break in observations. Observations since 1987 till 1993 were assigned to the first array. Observations since 1998 till 2002 were attributed to the second array.

Fig. 7 shows no noticeable drop in the Cas A and Cyg A spectral flux density ratio in the period since 1987 till 1993, with the average flux ratio of 1.5 at $25 \mathrm{MHz}$. During the period of minimum solar activity in 1987, the values of the Cas A to Cyg A flux ratio are close to the mean values and have the minimum variance. At the phase of growth, maximum and decline of the 22nd solar activity cycle, a large scatter of the Cas A to Cyg A flux ratio is observed with a noticeable increase in the variances of the mean values.

Fig. 8 shows a weak trend towards the decrease in the Cas A to Cyg A spectral flux density ratio. The data observed in the 23 rd solar activity cycle show a noticeable decrease in the CasA to Cyg A flux ratio 


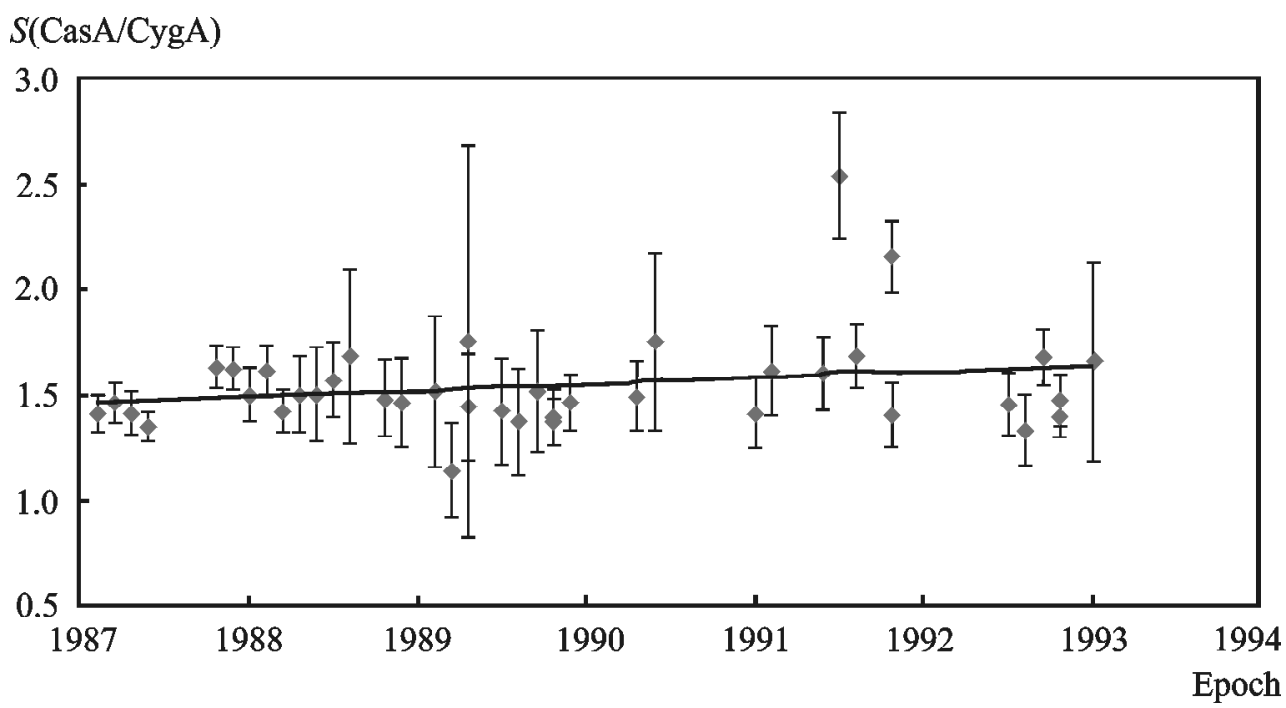

Fig. 7. Results of observations of the Cas A to Cyg A flux ratio made at the URAN-4 radio telescope with showing average flux ratio values for the observation period and their standard deviation

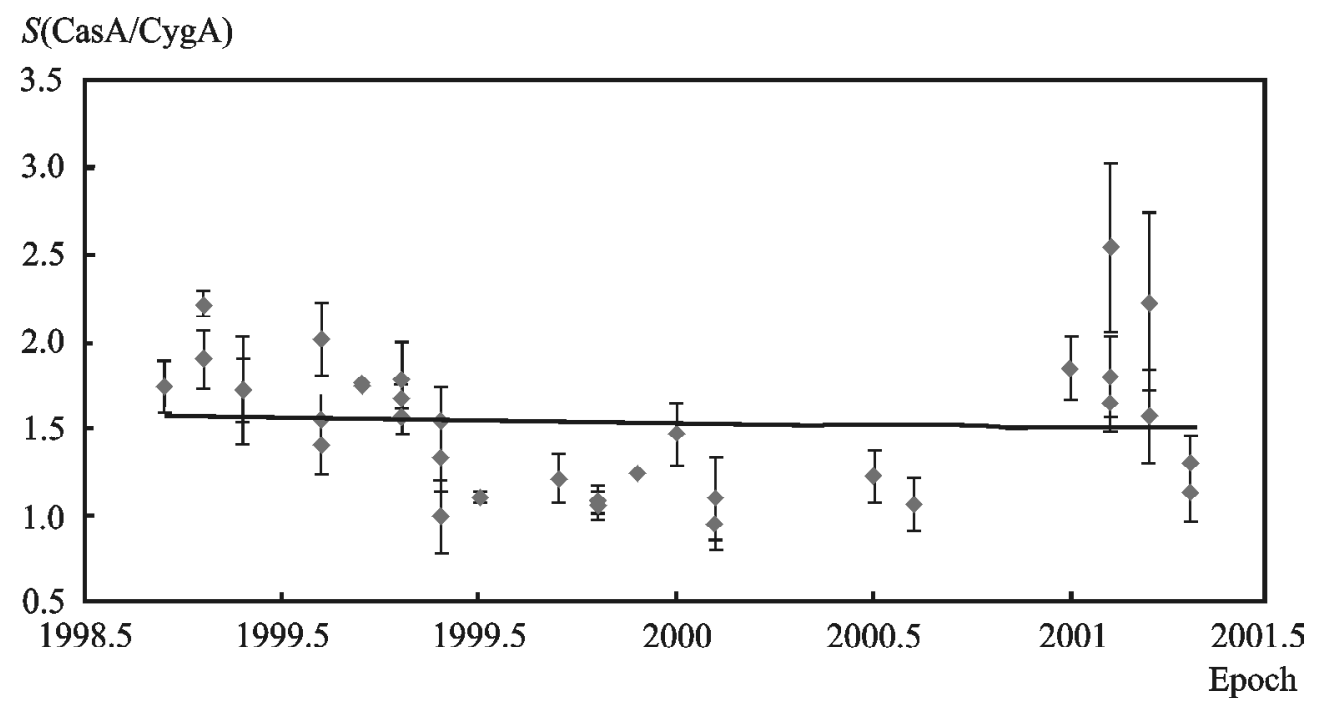

Fig. 8. Results of observations of the Cas A to Cyg A flux ratio made at the URAN-4 radio telescope in the period since 1998 till 2002

during the cycle maximum period, 1999-2000, which can be associated with the increased absorption in the ionosphere. In general, Figs. 7 and 8 show a secular decrease in the Cas A and Cyg A flux density ratio by $0.6 \%$ per year. Thus, the secular decrease in the Cas A flux at decameter waves shows weakly against the background of other influencing factors. During the increased solar activity period, the absorption of radio emission in the ionosphere at decameter waves increases, leading to a systematic decrease in the flux with the solar cycle activity development.

\section{Conclusions}

In the entire radio region, from centimeter to decameter wavelengths, there is a systematic deviation from the secular flux decrease trend of the Cas A radio source. Some of these deviations are associated with the seasonal-diurnal effect, the influence of the solar cycle during the solar and geomagnetic storms. At the same time, a significant part of the observed data is episodic that does not allow identifying unambiguously the causes of quasiperiodic changes. The compact source presence at the Cas A 
supernova remnant center can reveal itself in the radio flux evolution. All these factors open a prospect for making quasi-simultaneous observations in the range from centimeter to decameter wavelengths. Implementation of the joint program for observing Cas A and Cyg A flux variations with the RT-32, RT-16 radio telescopes and the LOFAR element of the Ventspils International Radio Astronomy Center, and the URAN, UTR-2 and GURT radio telescopes of the Institute of Radio Astronomy of the National Academy of Sciences of Ukraine is proposed.

\section{REFERENCES}

1. BAARS, J. W. M., GENZEL, R., PAULINY-TOTH, I. I. K. and WITZEL, A., 1977. The Absolute spectrum of Cas A: An Accurate Flux Density Scale and Set of Secondary Calibrators. Astron. Astrophys. vol. 61, is. 1, pp. 99-106.

2. STANKEVICH, K. S., IVANOV, V. P. and STOLYAROV, S. P., 1999. Fifty Years of Radio Observations of the Discrete Source Cassiopeia A. Astron. Lett. vol. 25, is. 8, pp. 501-507.

3. BARABANOV, A. P., IVANOV, V. P., STANKEVICH, K. S. and STOLYAROV, S. P., 1986. Evolution of the Cassiopeia A radio spectrum: evidence for cyclic variability. Sov. Astron. vol. 30, is. 5, pp. 549-554.

4. IVANOV, V. P. and STANKEVICH, K. S., 1989. Periodic variations of the radio emission and evolution of the spectrum of the supernova remnant Cassiopeia A. Sov. Astron. vol. 33 , is. 1 , pp. $15-20$.

5. TROTTER, A. S., REICHART, D. E., EGGER, R. E., STÝBLOVÁ, J., PAGGEN, M. L., MARTIN, J. R., DUTTON, D. A., REICHART, J. E.,. KUMAR, N. D, MAPLES, M. P., BARLOW, B. N., BERGER, T. A., FOSTER, A. C., FRANK, N. R., GHIGO, F. D., HAISLIP, J. B., HEATHERLY, S. A., KOUPRIANOV, V. V., LACLUYZÉ, A. P., MOFFETT, D. A., MOORE, J. P., STANLEY, J. L. and WHITE, S., 2017. The fading of Cassiopeia A, and improved models for the absolute spectrum of primary radio calibration sources. Mon. Not. R. Astron. Soc. vol. 469, is. 2, pp. $1299-1313$. DOI: $10.1093 / \mathrm{mnras} /$ stx 810

6. VINYAIKIN, E. N., 2007. Evolution of the radio spectrum of Cassiopeia A from long-term observations. Observations at 290 and $927 \mathrm{MHz}$. Astron. Rep. vol. 51, pp. 87-96. DOI: $101134 / \mathrm{S} 1063772907020023$

7. VINYAIKIN, E. N., 2014. Frequency dependence of the evolution of the radio emission of the supernova remnant Cas A. Astron. Rep. vol. 58, pp. 626-639. DOI: 101134/ S1063772914090078

8. MARTIROSSYAN, R. M., GOULYAN, A. G., SANAMYAN, V. A. and MANASELYAN, KH. A., 2020. Flux density variations of Cassiopea A radio source. Astrofizika. vol. 45, no. 3, pp. 443-449. (in Russian).

9. HELMBOLT, J. F. and KASSIM, N. E., 2009. The Evolution of Cassiopeia A at Low Radio Frequencies. Astron. J. vol. 138 , is. 3 , pp. $838-844$. DOI: $1088 / 0004-6256 / 138 /$ $3 / 838$
10. WALCZOWSKI, L. T. and SMITH, K. L., 1985. A recurrence of the Cassiopeia A flux anomaly. Mon. Not. R. Astron. Soc. vol. 212, is. 1, pp. 27P-31P. DOI: $10.1093 /$ mnras/212.1.27P

11. RYABOV, M. I., PANISHKO, S. K. and GUGLYA, L. I., 2011. Space weather impacts on the Earth's upper atmosphere according to the monitoring of powerful radio sources fluxes at the URAN-4 radio telescope (Institute of Radio Astronomy, NAS of Ukraine). Odessa Astronomical Publications. vol. 24, pp. 159-161. (in Russian).

12. GORBYNOV, A. A., RYABOV, M. I. and PANISHKO, S. K., 2015. Secular Decrease the Flux of Supernova Eemnant Cas A on Monitoring Results to Radiotelescope "URAN-4" IRA NASU. Odessa astronomical publications. vol. 28, no. 2 , pp. 224-226.

13. RYABOV, M. I. and SEROKUROVA, N. G., 1993. On the secular decrease of the radio flux Cas A at low frequencies. Astron. Astrophys. Trans. vol. 4, is. 1, pp. 29-32. DOI: 10.1080/10556799308205353

\section{A. А. Горбунов ${ }^{1}$, М. І. Рябов ${ }^{1,2}$, А. Л. Сухарєв ${ }^{2,3}$, B. В. Безруковс ${ }^{3}$}

${ }^{1}$ Одеський національний університет імені I. І. Мечникова, вул. Маразліївська, 1в, 65014, Одеса, Україна

${ }^{2}$ Обсерваторія “УРАН-4”, Радіоастрономічний інститут НАН України, вул. Маразліївська, 1в, Одеса, 65014, Україна

${ }^{3}$ Вентспілський міжнародний радіоастрономічний центр (VIRAC),

вул. Інженіеру, 101, м. Вентспілс, LV-3601, Латвія

\section{ПЕРІОДИЧНІ І СПОРАДИЧНІ ПРОЯВИ \\ ВАРІАЦІЙ СПЕКТРАЛЬНОЇ ЩІЛЬНОСТІ ПОТОКУ ВИПРОМІНЮВАННЯ ЗАЛИШКА НАДНОВОЇ СAS А}

Предмет і мета роботи: За даними багаторічних досліджень у всіх діапазонах радіоспектра розглядається характер відхилень спектральної щільності потоку випромінювання залишка наднової Cas А від тенденції ії вікового зменшення. Метою роботи $\epsilon$ визначення наявності квазіперіодичних варіацій та спорадичних змін спектральної щільності потоку випромінювання Cas А залежно від частоти.

Методи і методологія: Основною базою даних є опубліковані результати, отримані методом абсолютних вимірювань спектральної густини потоку випромінювання Cas А в діапазоні від міліметрових до дециметрових довжин хвиль, та результати, отримані методом відносних вимірювань, цебто співвідношення потоків випромінювання залишка наднової Cas А та радіогалактики Cyg A, що використовується як опорне джерело в діапазоні метрових довжин хвиль. Для співставлення із вказаними даними, знайденими різними методами, використано результати тривалого моніторингу (з 1987 р.) варіацій відношення спектральної щільності потоків Cas A та Суg А на радіотелескопі “УРАН-4” Радіоастрономічного інститута НАН України на частоті 25 МГц.

Результати: В результаті аналізу даних спостережень щільності потоку випромінювання Cas А у всьому радіодіапазоні відмічається існування квазіперіодичних варіацій 
в діапазоні від міліметрових до метрових довжин хвиль на часовому інтервалі від 2 до 9 років. Причиною виявлених квазіперіодичних варіацій можуть бути процеси в самому залишку Cas A. В діапазоні декаметрових довжин хвиль за даними моніторингу на радіотелескопі “УРАН-4” відмічаються сезонно-добові та довготривалі варіації, пов'язані зі зміною стану іоносфери в циклі сонячної активності, при слабкому прояві вікового зменшення потоку випромінювання Cas A. Наявність спорадичних варіацій відношення спектральних щільностей потоків Cas А та Cyg А пов'язана з проявами підвищеної сонячної активності. Аби пояснити зниження спектральної щільності потоку Cas A до рівня Cyg A та збереження перевищення потоку Cas A на декаметрових хвилях, слід виконувати квазіодночасні спостереження на радіотелескопах різних діапазонів.

Висновок: Еволюція залишку наднової Cas А залишається в центрі уваги сучасних досліджень. Інтригуючим моментом стало виявлення в центрі радіоджерела Cas А точкового рентгенівського джерела як можливого залишку наднової. Роль цього джерела у зменшенні вікового радіопотока Cas A та в його варіаціях ще належить 3'ясувати. Детальний аналіз багаторічних даних та виконання квазіодночасних спостережень дозволять виявити процеси, що відбуваються в самому радіоджерелі, та визначити, як на результати вимірювань впливає стан іоносфери. Пропонується спільна програма спостережень варіацій потоків випромінювання Cas A та Суg А на радіотелескопах РТ-32, РТ-16 і елементі радіоінтерферометра LOFAR Вентспілського радіоастрономічного центра (Латвія) та радіотелескопах “УРАН", "УТР-2" і ГУРТ Радіоастрономічного інститута НАН України.

Ключові слова: Cas A, вікове зменшення потоку випромінювання, залишок наднової, іоносфера, сонячна активність

Стаття надійшла до редакциї 08.11.2020 